\title{
The Analysis of Differences in Body Temperature and Blood Pressure Before and After Exposure to Hot Work Climates
}

\author{
Analisis Perbedaan Suhu Tubuh dan Tekanan Darah Sebelum dan Sesudah \\ Terpapar Iklim Kerja Panas
}

\author{
Sarah Nadhila Rahma, Mahfiro Risky Safitri, Abdul Rohim Tualeka \\ Department of Occupational Safety and Health, Faculty of Public Health, Universitas Airlangga \\ Campus C Mulyorejo, Surabaya, East Java, 60115 Indonesia
}

\begin{abstract}
Introduction: Working in a hot work environment has a negative impact on occupational health and safety. The impact on health due to work at temperatures above a comfortable temperature can affect body temperature and blood pressure of workers. The aim of this study was to analyze the differences in body temperature and blood pressure of workers before and after exposure to hot work climates at PT. Pertamina (Persero) Tanjung Wangi. Method: This research was an observational study with cross sectional approach. The population of this study was all workers at PT. Pertamina (Persero) Tanjung Wangi., with the total of 11 people. The sample in this study was obtained by total sampling method with a sample of 11 workers. The dependent variables in this study were body temperature, blood pressure, age, fluid intake, and nutritional status, while the independent variable was work climate. Results: Most of the grass lathe workers at PT. Pertamina (Persero) Tanjung Wangi has an age between 17-25 years, some of the grass lathe workers had a fluid intake with less categories with normal nutritional status. The measurement results showed that the average ISBB value was $28.8^{\circ} \mathrm{C}$, this value still exceeded TLV. In addition, the results showed that there were differences in body temperature before and after work, from $36.04^{\circ} \mathrm{C}$ to $36.8^{\circ} \mathrm{C}$. In addition there were differences in systolic and diastolic blood pressure before work which was $112.7 \mathrm{~mm} \mathrm{Hg} 77.3 \mathrm{~mm} \mathrm{Hg}$, and the average after work was $121 \mathrm{~mm} \mathrm{Hg}$ and $83.6 \mathrm{~mm} \mathrm{Hg}$. Conclusion: There is a difference between body temperature and blood pressure before and after exposure to hot work climates.
\end{abstract}

Keywords: blood pressure, body temperature, hot work climate

\section{ABSTRAK}

Pendahuluan: Bekerja di lingkungan kerja panas memiliki dampak buruk bagi kesehatan dan keselamatan kerja. Dampak bagi kesehatan akibat bekerja pada suhu di atas suhu nyaman diantaranya dapat mempengaruhi temperatur tubuh dan tekanan darah pekerja. Tujuan dari penelitian ini adalah untuk menganalisis perbedaan suhu tubuh dan tekanan darah sebelum dan sesudah terpapar iklim kerja panas pada petugas bubut rumput PT. Pertamina (Persero) Tanjung Wangi. Metode: Penelitian ini merupakan penelitian observasional dengan pendekatan cross sectional. Populasi penelitian ini adalah semua pekerja di PT. Pertamina (Persero) Tanjung Wangi, yang berjumlah 11 orang. Sampel dalam penelitian ini diperoleh dengan metode total sampling dengan sampel 11 pekerja. Variabel dependen yang diteliti yakni suhu tubuh, tekanan darah, usia, intake cairan, dan status gizi, dan variabel independennya adalah iklim kerja. Hasil: Sebagian besar tenaga kerja bubut rumput di PT. Pertamina (Persero) Tanjung Wangi memiliki usia antara 17-25 tahun, sebagian dari pekerja bubut rumput tersebut memiliki intake cairan dengan kategori kurang dengan status gizi normal. Dari hasil pengukuran menunjukkan bahwa rerata nilai ISBB adalah sebesar $28,8^{\circ} \mathrm{C}$, nilai ini masih melebihi TLV. Selain itu, hasil penelitian menunjukkan bahwa terjadi perbedaan suhu tubuh sebelum dan sesudah bekerja yaitu dari $36,04^{\circ} \mathrm{C}$ menjadi $36,8^{\circ} \mathrm{C}$. Selain itu terdapat perbedaan tekanan darah sistolik dan diastolic sebelum bekerja adalah sebesar $112,7 \mathrm{mmHg}$ $m$ 77,3 $\mathrm{mmHg}$, dan rerata sesudah bekerja adalah $121 \mathrm{mmHg}$ dan 83,6 mmHg. Simpulan: Ada perbedaan suhu tubuh dan tekanan darah sebelum dan sesudah terkena paparan iklim kerja panas. titis kontak.. Usia, masa kerja, dan riwayat penyakit memiliki hubungan yang lemah dengan kejadian dermatitis kontak.

Kata kunci: iklim kerja panas, suhu tubuh, tekanan darah

Corresponding Author:

Sarah Nadhila Rahma

Email: nadhila.sarah3098@gmail.com

Telephone: +6287755532010

(C2020 IJOSH All right reserved. Open access under CC BY NC-SA license doi: 10.20473/ijosh.v9i3.2020.318-327 Received May 19, 2020, received in revised form July 30, 2020, Accepted October 31, 2020, Published: November 2020 


\section{INTRODUCTION}

The definition of workplace according to Law Number 1 of 1970 concerning Occupational Safety in article 1 paragraph 1 is a room or field, closed or open, movable or permanent, which becomes a place of labor or is often entered by workers for the purposes of a business and sources of danger (Republic of Indonesia, 1970). The source of hazards in the workplace are varies, one of the sources of hazard in workplace is physical hazards, which is hot work climate (Ramli, 2010).

Each industry must have a production process, and not a few of these industries require hot temperatures. In line with such statement, the production process in an industry often requires high temperatures which are obtained from several heat sources steel smelting kitchens, ceramic kilns, gas smelting, etc (Soeripto M, 2008).

Work climate is a combination from air temperature, humidity, velocity of air flow and heat of radiation (Suma'mur, 2014). Hot working climate starts from the emergence of heat energy that comes from heat sources that are emitted directly or through intermediaries and enter the work environment, and become heat stress as an additional burden for worker (Soeripto M, 2008).

Exposed to high temperatures while working in a room with a hot environment or working in an outdoor with hot weather is included in working in hot work climates that can cause danger (Suma'mur, 2014). Similarly, according to one study, workers in hot environments such as smelters, boilers, ovens, heating stoves and outdoor work in the sun are exposed to hot work climates (Putriyani, 2016). Examples of outdoor work that is exposed to sun heat continuously such as in the brick industry, the boiler industry, the manufacture of sea salt, and grass lathe workers (Putriyani, 2016).

The work climate is usually measured by the Wet and Ball Temperature Index. This measurement is carried out to assess the results between dry air temperature, natural wet temperature and ball temperature. A workplace that is too hot can cause workers to get fatigue quickly due to loss of fluids and salt, plus if the worker has a heavy workload it will have a more severe impact on their health and safety (Putriyani, 2016). According to the Minister of Manpower Regulation No. 5 of 2018 concerning Occupational Safety and Health at Work Environment, the maximum value that workers can receive is 8 hours per day or 40 hours a week without causing health problems (Republic of Indonesia, 2018).
The comfortable temperatures for workers range between $24^{\circ} \mathrm{C}-26^{\circ} \mathrm{C}$, this is because this temperature is very suitable for tropical residents (Suma'mur, 2009). Temperature in the work environment is very influential on work efficiency. Low temperatures can reduce work efficiency. A temperature lower than a comfortable temperature can defeat stiffness and muscle deficiency. Working in a work environment that has high temperatures or extreme heat can have an impact on work health and safety (Tabita and Hendra, 2014). It can reduce the work performance of thinking, reduce the agility of workers, disrupt the accuracy of the work of the brain, disrupt the coordination of sensory and motor nerves and can also facilitate emotional stimulation. So that with the increase in temperature, it can endanger workers (Sunaryo and Sahri, 2019).

Workers exposed to heat exceeding the Threshold Limit Values (TLV) allowed will be able to experience illness due to work accidents that have an impact on decreasing work productivity. Hot work climate can cause both physiological and psychological disorders on worker (Suma'mur, 2014). An increase or decrease in environmental temperature can affect changes in blood pressure whether it is a decrease in blood pressure or an increase in blood pressure (Suma'mur, 2009).

One of study stated that the body temperature of workers experienced changes before being exposed to a hot work climate that was from $37.17^{\circ} \mathrm{C}$ to $38.17^{\circ} \mathrm{C}$ (Hemmatjo et al., 2017). Another difference in physiological responses due to the effects of a hot work climate is that according to research stating that there was an increase in systolic and diastolic blood pressure in workers after they were exposed to a hot work climate. The increase in heat pressure will be followed by an increase blood pressure (Lestari, 2018).

PT. Pertamina TBBM Tanjung Wangi has fuel oil products which include Pertamax, Premium, Fame, Solar, MDF, MFO, and Pertadex. In the process of its work, this company collaborates with other companies. One of PT. Patra Lima Jaya. PT. Patra Lima Jaya plays a role in the procurement of goods and services. One example of PT. Patra Lima Jaya is cleaning service workers who are in charge of grass lathe.

Grass lathe workers work in outdoor every day. Based on the results of the questionnaire to the worker, there were several subjective complaints felt by workers, among others, workers sometimes get dizzy after work, those who complained of dry skin, dry throat and so on. The symptoms get worse if the sun is hotter than usual. 
Based on the identification of the problems above, the researchers conducted a study to see whether there were differences in physiological responses of workers before and after exposure to the hot work climate of PT. Pertamina (Persero) Tanjung Wangi Fuel Oil Terminal (TBBM) which is related to the respondents' characteristics those are age, working period, intake fluid and related to work factors that is workload.

\section{METHODS}

This research method used an observational study because the data obtained were the results of questionnaires and direct measurements. Researchers did not provide treatment or intervention to respondents. This research was conducted at a certain time, therefore the research design used was cross section. Based on the way of analyzing data, this research was categorized as descriptive quantitative research since researchers described the differences in the results of the measurement of objects and the relationship between the dependent variable (physiological response of the body) and the independent variable (work climate) in the PT. Pertamina TBBM Tanjung Wangi.

The population of this research was all of grass lathe workers at PT. Pertamina TBBM Tanjung Wangi totaling 11 people. The sample in this study was obtained by total sampling method with a large sample of 11 workers.

The research location was in PT. Pertamina TBBM Tanjung Wangi located on Jalan Gatot Subroto Number 72 Banyuwangi District, East Java, Indonesia. The research was conducted in June 2019 until July 2019. In this study, several variables were used including work climate, body temperature, blood pressure, age, and fluid intake and nutritional status.

In this study, the data used were primary data and secondary data. Primary data collection was done by distributing questionnaires to the respondents in terms of age and fluid intake. In addition, primary data collection was done by checking nutritional status using the indicator Body Mass Index (BMI), measuring intake fluid from questionnaire, measuring work climate with Thermal Environment Monitor QUESTemp 36, measuring physical workload using 10 beats method by palpation, measuring blood pressure using manual tensimeter made from mercury and measuring body temperature with digital thermometer, and also conducted observations on the activities carried out by all grass lathe workers. Meanwhile, the secondary data collection aimed to collect supporting data obtained from company documents including a general description of the company and the number of workers in the grass lathe.

After that, the result data that has been recapitulated from the results of the study then presented using a frequency distribution table, and cross tabulation. In addition, a graph is presented showing the physiological responses of workers before and after work in a hot work climate. Then the data was processed and analyzed using the statistical test of Contingency Coefficient to measure the close relationship between physiological responses and work climate.

The study was approved by the institutional Ethical Board of the Faculty of Dental Medicine, Universitas Airlangga Surabaya. The number of ethics certificate is 339/HRECC.FODM/VI/2019.

\section{RESULTS}

\section{Characteristics of Individual Workers}

Grass Lathe Workers or commonly called cleaning services at PT. Pertamina TBBM Tanjung Wangi is outsource workers that owned by PT. Patra Lima Jay. The company is a subsidiary of PT. Pertamina. Grass lathe workers at PT. Pertamina (Persero) Tanjung Wangi Fuel Oil Terminal (TBBM) totaling 11 workers.

Grass lathe workers work every Monday to Friday for 8 hours starts from 07:30 to $15: 30$ with a break of 1 hour per day at 11:30 to 12:30. All activities carried out are exposed to the sun throughout the day.

Work activities carried out by grass lathe workers include preparing work equipment such as string machines and fuel and checking the machine to spend half an hour, followed by cutting grass for 5 hours, sweeping the area for 1 hour, moving and cleaning kliping grass and throwing them into the B3 waste area. Garbage from the grass cuttings were disposed in B3 waste area because some of the grass cutting areas have oil spills or other dangerous and toxic materials.

All workers in the grass lathe at PT. Pertamina TBBM Tanjung Wangi are male. The results of the study obtained data on workers characteristics including age, nutritional status, and fluid intake with a total worker of 11 people can be seen in the Table 1, Table 2, Table 3. 
Based on Table 1, it obtained information that the age of most labor was in the category $17-25$ years, by 5 people or $45.4 \%$. Table 2 shows that most of the nutritional status of the workers ie 6 people $(54.5 \%)$ were in the normal category with a BMI of $18.50-24.99 \mathrm{~kg} / \mathrm{m} 2$.

Then, rarely on Table 3 it can be considered that from questionnaire, the highest intake of worker fluid was in the lot category $(>200$ cc every $15-20$ minutes) and the less category ( $<200 \mathrm{cc}$ every $15-20$ minutes) as many as 4 workers with a percentage of $36.4 \%$ in each of these categories.

\section{Workload and Hot Work Climate on Grass Lathe Worker}

\section{Workers Workload}

In this study, the workload is the burden received by workers during the work process. Workload was measured by the 10 beat method and divided into 5 categories. The method was carried out if the electrocardiograph equipment was not available. The method was done by recording manually using a stopwatch with 10 pulses method (Puteri and Sukama, 2017). With this method the work pulse can be calculated as follows:

After calculating, the results were matched with a workload and work pulse table that contained 5

$$
\text { pulse }(\text { beat } / \text { minutes })=\frac{10 \text { pulse }}{\text { calculation time }} \times 60
$$

categories (Tarwaka, 2014). The distribution of the workload of labor can be shown in table 4 .

Based on Table 4, it is known that most of the workload was in the high category of 6 people with a percentage of $54.5 \%$ with a range of pulses in the high category of 125-150 beats / minute.

\section{Hot Work Climate}

Climate measurements were carried out at two points which became the work area of grass lathe workers, where each point was carried out 3 times, that were before the work was carried out, when the work takes place and after the work was done (Indonesian National Standard 16-7061, 2004). Work climate measurements were carried out in the bundwall area and the LLP warehouse area of PT. Pertamina TBBM Tanjung Wangi. This measurement was done in outdoor because the area work of the grass lathe worker was in outdoor. The following
Table 1. Age Distribution of Grass Lathe Worker at PT. Pertamina TBBM Tanjung Wangi in 2019

\begin{tabular}{ccc}
\hline Age (years) & Frequency (n) & Percentage (\%) \\
\hline $17-25$ & 5 & 45.4 \\
$26-35$ & 4 & 36.5 \\
$>35$ & 2 & 18.1 \\
\hline Total & 11 & 100 \\
\hline
\end{tabular}

Table 2. Nutrition Status Distribution of Grass Lathe Worker at PT. Pertamina TBBM Tanjung Wangi in 2019

\begin{tabular}{ccc}
\hline $\begin{array}{c}\text { Nutrition Status } \\
(\text { BMI) }\end{array}$ & Frequency (n) & Percentage (\%) \\
\hline Low $(<18.50 \mathrm{~kg} / \mathrm{m} 2)$ & 2 & 18.2 \\
Normal $(18.50-24.99$ & 6 & 54.5 \\
$\mathrm{~kg} / \mathrm{m} 2)$ & 3 & 27.3 \\
High $(\geq 25 \mathrm{~kg} / \mathrm{m} 2)$ & 11 & $100 \%$ \\
\hline Total & & \\
\hline
\end{tabular}

Table 3. Intake Fluid Distribution of Grass Lathe Worker at PT. Pertamina TBBM Tanjung Wangi in 2019

\begin{tabular}{ccc}
\hline $\begin{array}{c}\text { Nutrition Status } \\
(\mathbf{B M I})\end{array}$ & Frequency (n) & Percentage (\%) \\
\hline Low $(<18.50 \mathrm{~kg} / \mathrm{m} 2)$ & 2 & 18.2 \\
Normal $(18.50-24.99$ & 6 & 54.5 \\
$\mathrm{~kg} / \mathrm{m} 2)$ & 3 & 27.3 \\
High $(\geq 25 \mathrm{~kg} / \mathrm{m} 2)$ & 11 & $100 \%$ \\
\hline Total & &
\end{tabular}

Table 4. The Workload of Lathe Grass Workers at PT. Pertamina TBBM Tanjung Wangi in 2019

\begin{tabular}{ccc}
\hline Workload & Frequency (n) & Percentage (\%) \\
\hline $\begin{array}{c}\text { Low }(75-100 \text { beats/ } \\
\text { minutes })\end{array}$ & 0 & 0 \\
$\begin{array}{c}\text { Moderate }(100-125 \\
\text { beats/minutes })\end{array}$ & 5 & 45.5 \\
$\begin{array}{c}\text { High }(125-150 \text { beats/ } \\
\text { minutes })\end{array}$ & 6 & 54.5 \\
$\begin{array}{c}\text { Very High }(159- \\
175 \text { beats } / \text { minutes }) \\
\text { Extra High }(>175 \\
\text { beats } / \text { minutes })\end{array}$ & 0 & 0 \\
\hline Total & 11 & 0 \\
\hline
\end{tabular}


results of measurements of hot work climate shows as table 5 .

According to Table 5, it can be seen that the average WBGT Outdoor in the area of PT. Pertamina TBBM Tanjung Wangi that was equal to $28.8^{\circ} \mathrm{C}$ for point 1 and $28.6^{\circ} \mathrm{C}$ for point 2 . The highest average WBGT Outdoor value is $28.8^{\circ} \mathrm{C}$ found at point 1 .

\section{Differences in Body Temperature of Workers Before and After Exposure to Hot Work Climates}

According to Figure 1, it is known that the average body temperature of the labor before work was $36.04^{\circ} \mathrm{C}$ and the average body temperature of the workers after work was $36.8^{\circ} \mathrm{C}$. So that information can be obtained that there was an increase in body temperature between before and after work due to the hot work climate by $0.76^{\circ} \mathrm{C}$.

\section{Differences in Blood Pressure of Workers Before and After Exposure to Hot Work Climates}

According to Figure 2, it is known that the results of the average systolic blood pressure

Table 5. Hot Work Climate at PT. Pertamina TBBM Tanjung Wangi in 2019

\begin{tabular}{|c|c|c|c|c|c|c|}
\hline Location & $\begin{array}{l}\text { SBa } \\
\left({ }^{\circ} \mathrm{C}\right)\end{array}$ & $\begin{array}{c}\text { SK } \\
\left({ }^{\circ} \mathbf{C}\right)\end{array}$ & $\begin{array}{c}\mathrm{Sg} \\
\left({ }^{\circ} \mathrm{C}\right)\end{array}$ & $\begin{array}{c}\text { Wbgt o } \\
\left({ }^{\circ} \mathrm{C}\right)\end{array}$ & $\begin{array}{l}\text { M e a n } \\
0 \quad \text { f } \\
\text { WBGT }\end{array}$ & $\begin{array}{c}\mathrm{R}_{(\%)} \\
(\%\end{array}$ \\
\hline \multicolumn{7}{|c|}{ Point 1 (Bundwall) } \\
\hline Time 1 & 25.3 & 29.2 & 30.6 & 26.9 & & 69 \\
\hline Time 2 & 26.8 & 29.7 & 50.1 & 31.2 & 28.8 & 52 \\
\hline Time 3 & 25.4 & 29.3 & 37.7 & 28.4 & & 70 \\
\hline \multicolumn{7}{|c|}{ Point 2 (LLP Warehouse) } \\
\hline Time 1 & 25.4 & 29.3 & 30.7 & 26.9 & & 68 \\
\hline Time 2 & 26.1 & 29 & 49.3 & 30.5 & 28.6 & 70 \\
\hline Time 3 & 25.3 & 29.2 & 37.4 & 28.3 & & 70 \\
\hline Mean & 25.7 & 29.2 & 39.3 & 28.7 & 28.7 & 66.5 \\
\hline
\end{tabular}

Table 6. Cross Tabulation between Work Climate and Changes in Body Temperature of Lathe Grass Workers at PT. Pertamina TBBM Tanjung Wangi in 2019

\begin{tabular}{cccccccc}
\hline \multirow{2}{*}{ Work Climate } & \multicolumn{3}{c}{$\begin{array}{c}\text { Ch a nge } \\
\text { Temperature After Work }\end{array}$} & \multirow{2}{*}{ Total } \\
\cline { 2 - 5 } & \multicolumn{2}{l}{ Decrease } & \multicolumn{2}{c}{ Increase } & & \\
\cline { 2 - 6 } & $\mathbf{n}$ & $\mathbf{\%}$ & $\mathbf{n}$ & $\mathbf{\%}$ & $\mathbf{N}$ & $\mathbf{\%}$ \\
\hline $\begin{array}{c}\text { Not Exceed } \\
\text { TLV }\end{array}$ & 1 & 20 & 4 & 80 & 5 & 100 \\
Exceed TLV & 0 & 0 & 6 & 100 & 6 & 100 \\
\hline
\end{tabular}

examination before work was $112.7 \mathrm{mmHg}$, while the average after work was $121 \mathrm{mmHg}$. So it is known that there was differences between systolic blood pressure before and after work.

Based on Figure 3, it showed that the average diastolic blood pressure before work was 77.3 $\mathrm{mmHg}$, while the average after work was 83.6 mmHg. So it is known that there was differences between diastolic blood pressure before and after work.

\section{Cross Tabulation between Work Climate and Body Physiological Response}

Table 6 shows that out of 11 workers working in hot work climate, 6 workers $(60 \%)$ had body temperature exceeding the TLV, while the other 4 workers $(40 \%)$ have an increase in body temperature but did not to exceed the TLV. Furthermore, workers in the category not exceeding TLV experienced a decrease in body temperature by $100 \%$, as many as 1 worker. From these results, a statistical test was carried out and a contingency coefficient value of 0.327 was obtained. The value is close to 0 , meaning that the strength of the relationship between work climate and body temperature is weak with the direction of a positive relationship.

In Table 7, it is known that 11 workers working in the work climate with the category Exceeding the TLV and Not Exceeding the TLV each contained 4 workers, that are $66.67 \%$ and $80 \%$ who had an increase in systolic blood pressure, 1 worker in each category exceeded TLV by $16.67 \%$ and Not Exceeding TLV by $20 \%$ did not experience a decrease in systolic blood pressure and 1 worker experienced a decrease in systolic blood pressure after working in the work climate Exceeding the TLV by $16.67 \%$. From the results of statistical tests obtained a contingency coefficient value of 0.277 . This value is close to 0 , meaning that the relationship

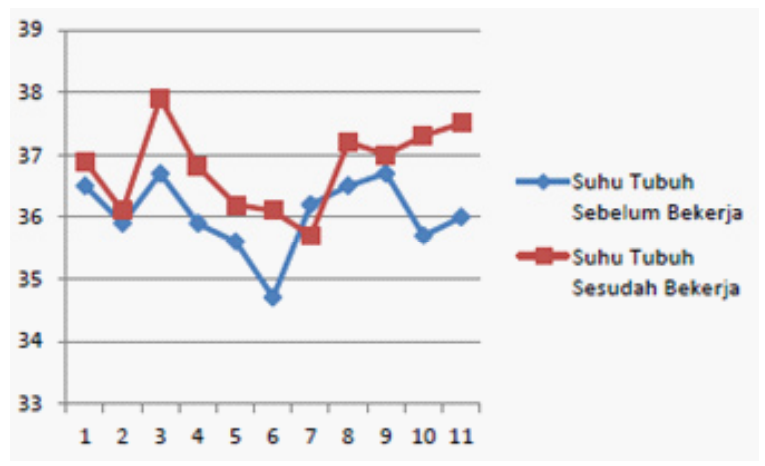

Figure 1. Graph of Difference in Body Temperature Before and After Working 


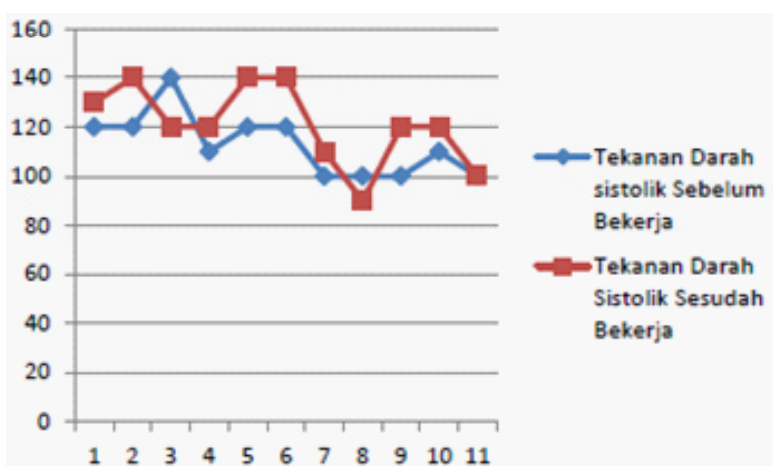

Figure 2. Graph of Differences in Systolic Blood Pressure Before and After Working

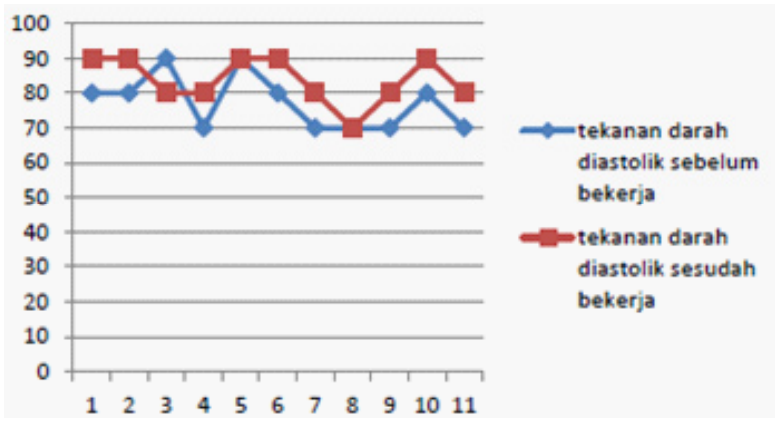

Figure 3. Graph of Differences in Diastolic Blood Pressure Before and After Working

between work climate and changes in systolic blood pressure was weak with the direction of a positive relationship.

Rely on Table 8, we know that the cross tabulation between work climate and changes in diastolic blood pressure. The results showed that among 11 workers working in the work climate in the category of Exceeding TLV and Not Exceeding TLV each contained 4 workers, which is $66.67 \%$ and $80 \%$ had an increase in diastolic blood pressure, 1 worker in each work climate category exceeds the TLV by $16.67 \%$ and those who did not exceed TLV by $20 \%$ had not decrease in diastolic blood pressure and 1 worker had decrease in diastolic blood pressure after work in the work climate category Exceeds the TLV which was $16.67 \%$. From the results of statistical tests, it obtained a contingency coefficient value of 0.277 .

\section{DISCUSSION}

\section{Characteristics of Individual Worker}

A person's age is directly proportional to his physical work capacity. The older a person, the
Table 7. Cross Tabulation between Work Climate and Changes in Systolic Blood Pressure of Lathe Grass Workers at PT. Pertamina TBBM Tanjung Wangi in 2019

\begin{tabular}{|c|c|c|c|c|c|c|c|c|}
\hline \multirow{3}{*}{$\begin{array}{l}\text { W o r k } \\
\text { Climate }\end{array}$} & \multicolumn{6}{|c|}{$\begin{array}{c}\text { Changes in Systolic Blood Pressure } \\
\text { After Work }\end{array}$} & \multirow{2}{*}{\multicolumn{2}{|c|}{ Total }} \\
\hline & \multicolumn{2}{|c|}{ Decrease } & \multicolumn{2}{|c|}{ Stuck } & \multicolumn{2}{|c|}{ Increase } & & \\
\hline & $\mathbf{n}$ & $\%$ & $\mathbf{n}$ & $\%$ & n & $\%$ & $\mathbf{N}$ & $\%$ \\
\hline $\begin{array}{c}\text { Not } \\
\text { Exceed } \\
\text { TLV }\end{array}$ & 0 & 0 & 1 & 20 & 4 & 80 & 5 & 100 \\
\hline $\begin{array}{l}\text { Exceed } \\
\text { TLV }\end{array}$ & 1 & 16.67 & 1 & 16.67 & 4 & 66.67 & 6 & 100 \\
\hline
\end{tabular}

Table 8. Cross Tabulation between Work Climates with Changes in Blood Pressure Diastolic of Lathe Grass Workers at PT. Pertamina TBBM Tanjung Wangi in 2019

\begin{tabular}{|c|c|c|c|c|c|c|c|c|}
\hline \multirow{4}{*}{$\begin{array}{l}\text { W o r k } \\
\text { Climate }\end{array}$} & \multirow{2}{*}{\multicolumn{6}{|c|}{$\begin{array}{c}\text { Changes in Diastolic Blood Pressure } \\
\text { After Work }\end{array}$}} & \multirow{3}{*}{\multicolumn{2}{|c|}{ Total }} \\
\hline & & & & & & & & \\
\hline & \multicolumn{2}{|c|}{ Decrease } & \multicolumn{2}{|c|}{ Stuck } & \multicolumn{2}{|c|}{ Increase } & & \\
\hline & $\mathbf{n}$ & $\%$ & n & $\%$ & n & $\%$ & $\mathbf{N}$ & $\%$ \\
\hline Not & & & & & & & & \\
\hline $\begin{array}{c}\text { Exceed } \\
\text { TLV }\end{array}$ & 0 & 0 & 1 & 20 & 4 & 80 & 5 & 100 \\
\hline $\begin{array}{c}\text { Exceed } \\
\text { TLV }\end{array}$ & 1 & 16.67 & 1 & 16.67 & 4 & 66.67 & 6 & 100 \\
\hline
\end{tabular}

higher his physical. Physical work capacity will be maximum for someone who is 25 years old (Tarwaka, 2014). The ability of physical work will decrease by $25 \%$ over the age of 50-60 years. This will have an impact on the negligence in doing every activity or work.

The result of the study showed that it can be considered that the oldest age of the grass lathe workers of PT. Pertamina TBBM Tanjung Wangi was 52 years old while the youngest was 21 years old. For the most age group was the age group of $17-25$ years by 5 people or $45.5 \%$. This is consistent with the theory that the most age group of workers is 17-25 years old. However, there were some workers who are more than 50 years old on the grounds that these workers are long time workers at PT. Pertamina TBBM Tanjung Wangi and already an expert as a grass lathe workers so that the company continues to employ the workers. This is in line with research which assumed that workers with long working periods are skilled at work but the heat exposure they receive is even greater (Adiningsih, 2013) 
Most of the workers had normal nutritional status by 6 people (54.5\%). Those who had more than normal nutritional status were 2 people, while those who had less than normal nutritional status were 3 people. Someone who has a body mass index (BMI) in the less category has a low oxygen intake and is less tolerant of heat than those who have a body mass index in the normal category (Guyton and Hall, 2016)

There are 5 people with abnormal nutritional status so that the company can give more attention to the nutritional status of grass lathe workers. Lack of nutrient consumption for a person of the minimum standard will generally affect health conditions, activities and work productivity (Utami, 2014). So it is very important for companies to monitor the consumption of worker nutrition, especially workers who work in hot work climates. Because workers exposed to hot work climates require more calories than workers not exposed to hot work climates (Suryaningtyas and Widajati, 2017)

Grass lathe workers have body fluid intakes that are in the Less and High categories, each with 4 people. Meanwhile, the remaining 3 people had enough or sufficient body fluid intake. Basically the consumption of fluids has an important role for workers who are exposed to heat. When workers are exposed to hot work climates, workers will lose water which the form is sweat whose purpose is for cooling and evaporation. The lost water must be replaced by drinking water which is adjusted to the rules so that dehydration does not occur for workers (Soeripto M, 2008).

\section{Workload and Hot Work Climate on Grass Lathe Worker}

\section{Workload of Worker}

Workload received by the worker will be used to determine the work time according to the ability and physical work capacity of the worker (Tarwaka, 2014). Excessive workload causes the supply of oxygen in the tissue will be reduced so that the release of carbon dioxide is limited and lactic acid accumulates. This can cause fatigue in worker to emerge more quickly (Suma'mur, 2014). So that worker productivity can be optimized, workers can avoid work-related diseases and work accidents need to be adjusted to workload and work capacity (Suma'mur, 2014).

The workload value was obtained from the calculation of the workload with the 10 beat method with 5 categories of workload. So the less amount of time produced in reaching 10 beats, the more workload values will be generated so the higher the workload category. The results of this study mentioned that the workers of the grass lathe worker who had a high workload category were 6 people and workers with a moderate workload category were 5 people. From the results of the measurement of the workload, it obtained that most of the workers had a high workload. In line with one of studies about workload, it explained that the workload of workers in PT. X is very high, the higher workload provided by the company, the more increased fatigue in worker (Delima, 2018). Therefore, improvement efforts need to be made to adjust the workload and work capacity of the workers.

\section{Hot Work Climate}

The measurement of hot work climate used the Therma Environment QUESTemp 36 tool which was carried out at 2 points that were in the tank area (Bundwall) and LLP warehouse yard area. Measurements were made 3 times at each point, there were before the work was carried out, when the work took place and after the work was done. The selection of points based on these points was the work area of the grass lathe workers.

The result of measurement of hot work climate in the tank area (Bundwall) and in the LLP warehouse yard area results in an average value of ISBB which was $28.8^{\circ}$, where the physical workload of worker in the high category was $125-150$ beats/minute and the moderate category was $100-125$ beats/ minute and the working time setting was $75-100 \%$ of 8 work hours. Referring to Minister of Manpower Regulation No. 5 of 2018 concerning Occupational Safety and Health at Work Environment, the Wet and Ball Temperature Index value in the work area of grass lathe workers have exceeded the Threshold Value Limit determined for the medium category which was $28^{\circ} \mathrm{C}$ and for the high workload category which was $27.5^{\circ} \mathrm{C}$ (Republic of Indonesia, 2018).

The hot work climate received by workers when it has exceeded the established tolerance can cause physiological disorders. That is why the workplace with high temperature needs to get more supervision than the workplace with low temperature (Suma'mur, 2014). This is important because the exposure to hot working climate that exceeds the Threshold Limit Values (TLV) allowed can lead to Occupational Disease and Work Accidents so that it can reduce work productivity. 


\section{Differences in Body Temperature of Workers Before and After Exposure to Hot Work Climates}

The results of the examination of the body temperature of the grass lathe workers at PT. Pertamina (Persero) TBBM Tanjung Wangi before and after work noted that there was an increase in body temperature. The average body temperature before work was $36.04^{\circ} \mathrm{C}$ and after work it rose to $36.8^{\circ} \mathrm{C}$. From that, it can be concluded that there was a difference between the body temperatures of workers before and after exposure to hot working climates.

However, the rise in body temperature of the workforce was still within the safe limits of normal human body temperature. The body temperature of people working at Traditional Ports in Indramayu in 2018 increased after work, the results obtained the body temperature of workers before being exposed to heat by $36.14^{\circ} \mathrm{C}$ and the average body temperature of workers after being exposed to heat that was 37.1 ${ }^{\circ} \mathrm{C}$ (Amaliya, Supriyanto and Ginanjar, 2019).

An expert stated that the constant body temperature of workers was $37^{\circ} \mathrm{C}$ (Soeripto $\mathrm{M}$, 2008). This statement is also the same as the statement that humans will be able to survive with body temperature below $38^{\circ} \mathrm{C}$ (Suma'mur, 2014), so that workers still feel comfortable when the average body temperature of the worker is $36.8^{\circ} \mathrm{C}$. If the body temperature was more than $38^{\circ} \mathrm{C}$ it can be ascertained that the workforce experienced heat strain (Suma'mur, 2014). When a person is exposed to heat strain, and the release of heat is not balanced with the heat produced by the body, then the body temperature will continue to rise to an unsafe level (Cahyaningsih, 2018).

The study also found that there were workers whose body temperature has decreased, this is in accordance with the statement that when workers experience heat loss through blood circulation, the body will maintain internal body temperature in order to remain in a normal state between the body and the environment (Soeripto M, 2008).

\section{Differences in Blood Pressure of Workers Before and After Exposure to Hot Work Climates}

Systolic blood pressure checks on grass lathe workers have increased before and after work due to heat exposure at PT. Pertamina TBBM Tanjung Wangi. The average value for systolic blood pressure before work was $112.7 \mathrm{mmHg}$ while the average value of blood pressure after work was $121 \mathrm{mmHg}$ so that it has increased by $8.3 \mathrm{mmHg}$. Systolic blood pressure increases as well as diastolic blood pressure which has increased before and after work ie for blood pressure before work was $77.3 \mathrm{mmHg}$ while blood pressure after work was $83.6 \mathrm{mmHg}$ so that it has increased by 6.3 .

The results of the above study are the same as the results of a study which results in an average systolic blood pressure of workers before being exposed to heat which was $116.33 \mathrm{mmHg}$ and after exposure to heat that was $123.29 \mathrm{mmHg}$ (Pradana, 2016), while the average diastolic blood pressure before and after exposure to hot working climate namely $79 \mathrm{mmHg}$ and $80.89 \mathrm{mmHg}$. Also showed an increase in systolic and diastolic blood pressure which is significant in workers before and after work in hot environment (NurIzzat et al., 2015)

Workers who are exposed to hot work climates will have an increase in blood pressure along with an increase in air temperature in the work environment (Suma'mur, 2014). Blood pressure can indicate a condition where the pressure imposed by blood on arteries when blood is pumped by the heart to all members of the body (Guyton and Hall, 2016). While the decrease in blood pressure is due to the adequacy of fluids in the body.

\section{Cross Tabulation between Work Climate and Body Physiological Response}

Statistical test results between work climate and body physiological response of contingency coefficients at each body temperature, systolic blood pressure and diastolic blood pressure were 0.327 , 0.277 and 0.277 . All statistical test results indicate that the relationship between work climate and the body's physiological response is weak because the value of the contingency coefficient approaches 0 , with the direction of a positive relationship. The statistical test results are in accordance with the opinion that the longer worker in hot work climate conditions, the more additional burden, so it will cause physiological effects like increased fatigue, heart rate, blood pressure, body temperature, also increased sweat production excessive (Soeripto M, 2008).

The closeness of the relationship in the weak category can be caused because there was not only one factor that affects the difference in physiological responses, but there were several factors such as workload, time duration of work, and environment temperature. This is also supported by the statement 
that blood pressure is also influenced by the age of the workforce not only influenced by the work climate or work environment, but individual factors also affect the body's physiological response (Guyton and Hall, 2016).

Based on several things above, if there is exposure to hot work climate in high level, it will cause changes in the body's physiological response to more severe. So that, the company need to make control such as the supply of drinking water to prevent dehydration, the provision of suitable work clothes, the rest hour system for workers.

\section{CONCLUSION}

The characteristics of grass lathe workers in PT. Pertamina TBBM Tanjung Wangi are all workers are male, most of workers aged 17-25 years $(45.4 \%)$, some have fluid intake in the low category $(36.4 \%)$ with nutritional status is normal $(54.5 \%)$. The workload of grass lathe workers mostly classified as high workload. The hot work climate in the tank area (bundwall) shows that it has exceeded the standard $\left(28.8^{\circ} \mathrm{C}\right)$, whereas in the LLP area and warehouse area is still below standard $\left(28.6^{\circ} \mathrm{C}\right)$. The result of measurement shows that the average body temperature before work and after work has increased, it means that there are differences in body temperature before and after work. In addition, the mean systolic and diastolic blood pressure also shows a difference between before and after work. But the relationship between the body temperature and blood pressure with a hot work climate is included in the weak category with a positive direction.

\section{ACKNOWLEDGMENT}

The author would like to say thank to the Faculty of Public Health of Universitas Airlangga. The author would also like to thank several parties especially to Mahfiro Risky because without the support and assistance of them this article cannot finish smoothly and complete on time.

\section{REFERENCES}

Adiningsih, R. (2013) 'Faktor yang Mempengaruhi Kejadian Heat Strain pada Tenaga Kerja yang Terpapar Panas di PT Aneka Boga Makmur', The Indonesian of Occupational Safety and Health, 2(2), pp. 145-153.
Amaliya, L. R., Supriyanto and Ginanjar, R. (2019) 'Hubungan Tekanan Panas Terhadap Suhu Tubuh dan Denyut Nadi Pada Masyarakat yang Bekerja di Lingkungan Pelabuhan Tradisional Desa Eretan Wetan Kecamatan Kandanghaur Kabupaten Indramayu Tahun 2018', PROMOTOR Jurnal Mahasiswa Kesehatan Masyarakat, 2(1), pp. 37-43.

Cahyaningsih, D. A. (2018) 'Keluhan Subjektif Akibat Paparan Panas pada Operator dan Pemeliharaan Boiler PT.IP tahun 2018', Jurnal Kesehatan Lingkungan, 7(1), pp. 52-66.

Delima, R. H. (2018) 'Pengaruh Beban Kerja Terhadap Kelelahan Kerja (Studi Kasus pada Karyawan PT. Adira Dinamika Multi Finance Cabang Muara Bungo)', Jurnal Ilmiah Universitas Batanghari Jambi, 18(2), pp. 230-239.

Guyton, A. . and Hall, J. (2016) Text Book of Medical Physiologi. New York: W.B Saunders Company.

Hemmatjo, R. et al. (2017) 'The Effect of Various Hot Environments on Physiological Responses and Information Processing Performance Following Firefighting Activities in a Smoke-Diving Room', National Intitutes of Health, 8(4), pp. 386-392.

Indonesian National Standard 16-7061 (2004) Concerning Measurement of hot working temperature with Wet and Ball Temperature Indication Parameters. Jakarta: The Standarization Council of Indonesia.

Lestari, D. (2018) 'Hubungan Paparan Panas Dengan Tekanan Darah Pada Pekerja Pabrik Baja Lembaran Panas', Jurnal Kesehatan Masyarakat (e-Journal), 6(6), pp. 79-86.

NurIzzat, S. et al. (2015) 'Study on Physiological Effects on Palm Oil Mill Workers Exposed to Extreme Heat Condition', Journal of Scientific and Industrial Research, 74(7), pp. 406-410.

Pradana, T. (2016) 'Perbedaan Efek Fisiologis pada Pekerja Sebelum dan Sesudah Bekerja Di Lingkungan Kerja Panas', Jurnal Vokasi Kesehatan, 2(1), pp. 49-54.

Puteri, R. and Sukama, Z. (2017) 'Analisis Beban Kerja dengan Menggunakan Metode CVL dan NASA-TLX di PT.ABC', Spektrum Industri, 15(2), pp. 121-255.

Putriyani, A. (2016) 'Perbedaan Kelelahan Kerja yang Terpapar Iklim Kerja Panas Pada Pekerja Bagian Pengecekan dan Perbaikan di PT. Kereta Api Daerah Operasi VI Yogyakarta Dipo Kereta aPI Solo Balapan', Jurnal Kesehatan, 9(2), pp. 307-318. 
Ramli (2010) Pedoman Praktis Manajemen Risiko dalam Perspekktif K3 OHS Risk Management. Jakarta: Dian Rakyat.

President of the Republic of Indonesia (1970) Law Number 1 of 1970 concerning Occupational Safety. Jakarta: State Secretary of the Republic of Indonesia .

Minister of Manpower (2018) Regulation No. 5 of 2018 concerning Occupational Safety and Health at Work Environment. Jakarta: Ministry of Manpower.

Soeripto M (2008) Higiene Industri. Jakarta: Fakultas Kedokteran Universitas Indonesia.

Suma'mur (2009) Higiene Perusahaan dan Kesehatan Kerja (HIPERKES). Jakarta: Sagung Seto.

Suma'mur, S. \& (2014) Kesehatan Kerja dalam Perspektif Hiperkes dan Keselamatan Kerja. Jakarta: Erlangga.

Sunaryo, M. and Sahri, M. (2019) 'Evaluasi Iklim Kerja di Bagian Produksi pada Industri Keramik di Wilayah Gresik', ARTERI : Jurnal Ilmu Kesehatan, 1(1), pp. 29-35.
Suryaningtyas, Y. and Widajati, N. (2017) 'Iklim Kerja dan Status Gizi Dengan Kelelahan Kerja Pada Pekerja Di Ballast Tank Bagian Reparasi Kapal Pt. X Surabaya', Jurnal Manajemen Kesehatan Yayasan RS.Dr. Soetomo, 3(1), p. 17.

Tabita and Hendra (2014) 'Gambaran Keluhan Subyektif Akibat Pajanan Tekanan Panas Paa Pekerja Kebersihan PT X Mitra Kerja PT Indonesia Power Unit Bisnis Pembangkit Suralaya Tahun 2014', National Public Health Journal, 2(2), pp. 36-53.

Tarwaka (2014) Keselamatan dan Kesehatan Kerja, Manajemen Implementasi K3 di Tempat Kerja. Surakarta: Harapan Press.

Utami, S. R. (2014) 'Hubungan Antara Status Gizi Dan Tingkat Kebugaran Jasmani Dengan Produktivitas Kerja Pada Tenaga Kerja Wanita Unit Spinning 1 Bagian Winding Pt. Apac Inti Corpora Bawen', Unnes Journal of Public Health, 3(1), pp. 1-9. 